\title{
DA MPB AO RAP - VIRTUOSISMO, TÉCNICA, JULGAMENTOS NA ESTÉTICA MUSICAL
}

FROM MPB TO RAP - VIRTUOSITY, TECHNIQUE, JUDGMENTS IN THE MUSICAL AESTHETICS

Pablo Augusto Silva ${ }^{1}$

\section{Resumo}

Esse artigo formula algumas hipóteses para se analisar o papel da música popular na cultura brasileira contemporânea, da MPB (música popular brasileira) ao rap. Uma delas é a correlação entre o predomínio da racionalidade técnica e da especialização nas esferas sociais do trabalho e da economia e o surgimento, na modernidade, do virtuose, o artista profissionalmente educado para executar em alto grau técnico a sua arte. Sob a perspectiva da sociologia compreensiva, tomamos alguns agentes e instituições da esfera musical para problematização e crítica da cultura contemporânea. Nossas fontes de pesquisa são a música popular brasileira de vanguarda (a MPB), que desde os anos 1960 vem sendo socialmente reconhecida como expressão da "genuína cultura brasileira", e o rap, expressão musical de uma significativa parcela da juventude urbana a partir dos anos 1980 até a atualidade.

Palavras-chave: Música Popular; Rap; Virtuose; Técnica; Julgamento; Sociologia da Música.

\footnotetext{
${ }^{1}$ Mestre em Sociologia/Unicamp. pablo.gutto@gmail.com
} 


\section{Gostos de classe, gostos musicais: o popular e o erudito}

A peculiaridade da música, ou da pop music, em relação às outras artes na esfera da cultura advém do seu caráter de universalidade, "sem fronteiras", reforçado ainda mais nos países ocidentais e suas periferias no pós-II Guerra, com o alastramento da indústria cultural. Se no século XIX a música tomou para si a função de expressar, na esfera estética, a identidade de povos e nações - de Wagner a Carlos Gomes -, no século XX, nenhuma outra arte expressou de modo tão veemente as antinomias das identidades nacionais, principalmente em sua vertente popular (jazz, rock, tropicalismo, rap). O prestígio e a universalidade da música, de concerto e/ou popular, na esfera da cultura devem-se ao fato dela atrair como um imã a poesia, a dança, a dramaturgia e as artes visuais com muito mais força e ênfase do que os outros meios de expressão artísticos fazem com suas vizinhas. Todavia, a sua dimensão e importância na esfera cultural ainda foram pouco analisadas pelas ciências sociais. Nosso artigo é um fragmento com o intuito de lançar um grão nesse mar da cultura contemporânea. Trata-se antes de algumas notas e tentativas de formulação de hipóteses para se analisar o papel da música popular na cultura brasileira contemporânea, do tropicalismo ao rap. Uma de nossas hipóteses é que a idéia de utopia e romantismo enquanto crítica da racionalidade da sociedade burguesa - "o romântico é, por essência, uma reação contra o modo de vida da sociedade capitalista (Löwy; Sayre, 1995, p. 34)" - talvez esteja presente hoje de maneira explícita apenas no rap, com sua crítica à arte pela arte; no entanto, os seus produtores, ao contrário da geração dos CPCs - os Centros Populares de Cultura, iniciados pelos estudantes da UNE nos anos 1960 (Berlinck, 1984; Hollanda, 1981) -, são jovens originários das classes populares. Isso acarreta conseqüências no processo de legitimação de seus trabalhos: os julgamentos estéticos sobre essa produção cultural, analisado sociologicamente, revelam muito menos crítica cultural e muito mais julgamentos de gostos de classe e de gerações diferentes das desses jovens, até mesmo por aqueles que simpatizam com tal produção; isso impede não apenas uma comunicação e interação entre agentes culturais de gerações e classes sociais distintas, como a própria avaliação estética desses novos trabalhos. Assim, trata-se aqui de tomar o rap mais como um ponto de partida para uma crítica da cultura contemporânea por intermédio da esfera musical do que de um estudo sobre o rap enquanto um novo tipo de gênero ou de estilo propriamente ditos.

O rap "é pobre do ponto de vista estético"; suas batidas "são repetitivas", o que acaba tornando a música monótona, ao contrário de outros tipos de música popular. Essas 
afirmações sobre o rap, tiradas das seções culturais de revistas semanais e jornais diários, revelam não só uma análise estética, mas antes um julgamento de gosto. Enquanto julgamento de gosto é compreensível, visto que as preferências dos indivíduos são explicadas partindo de suas trajetórias sociais; julgamento de gosto de classe que também representa um estilo de vida. A maioria dos críticos que enfatiza a sua 'pobreza estética' geralmente são indivíduos originários da classe média intelectualizada. Isso pode ser lido e visto nas seções culturais dos principais jornais e programas de TV, ouvido em palestras ou conferências sobre cultura contemporânea, e em oficinas e cursos oferecidos em importantes instituições culturais.

O gosto musical da classe média intelectualizada costuma ser a "música popular de vanguarda", a MPB, quase um gênero musical com suas ramificações: bossa nova, tropicalismo, e "músicas populares de qualidade", segundo as propagandas das rádios que tocam esse tipo de música e enfatizam (e ao mesmo tempo legitimam) compositores como Tom Jobim, Chico Buarque, Gilberto Gil, Caetano Veloso, João Gilberto, Tom Zé dentre outros. Basta sintonizar uma rádio universitária para se ter maior noção desse gosto musical. Os livros sobre música brasileira nas estantes das livrarias são deste 'gênero' e/ou sobre estes músicos e até mesmo destes músicos, que costumam ter uma boa recepção crítica e vender muito bem, como os romances de Chico Buarque ou o livro de Caetano Veloso (1997). Gênero musical que se torna relativamente autônomo a partir dos anos 1960, com os movimentos culturais da época e, a seguir, com a inserção profissional desses compositores, poetas e músicos em uma nascente indústria do entretenimento, época em que se inicia a hegemonia da indústria cultural no Brasil.

Se perguntado a um acadêmico ou a algum músico erudito - "erudito" aqui utilizado para demarcar a fronteira simbólica que há entre eles e o "músico popular" (melhor seria dizer apenas músico, de uma orquestra ou de concerto, mas o universo social é cheio de hierarquias que não podemos simplesmente ignorar) - melhor dito, se analisado os seus discursos e estilos de vida das coisas mais "insignificantes" como os ambientes que frequentam

\footnotetext{
${ }^{2} \mathrm{O}$ termo MPB enquanto "música popular brasileira de vanguarda", não é um conceito científico (sociológico) que nós construímos a priori. Parece um paradoxo, mas é a própria história com os seus agentes que, aos poucos, vem legitimando esse termo para diferenciar, de fato, a música popular produzida por músicos originários de ambientes universitários daqueles originários de ambientes não-universitários. Muitas rádios que tocam "música popular brasileira", raramente tocam as músicas que, de fato, as classes populares brasileiras consomem e ouvem: pagode, forró, axé music, funk, sertanejo, rap, gêneros cujos músicos são majoritariamente nãouniversitários. Basta sintonizar o rádio em qualquer estação universitária ou correlata para perceber que, quando estes gêneros são tocados, é quase sempre como "objeto de estudo" em programas especiais ou entrevistas com "especialistas" e não para fruição estética. Em S. Paulo temos alguns exemplos: as rádios Cultura Brasil AM, Eldorado, Nova Brasil, USP etc. Caetano Veloso (1997) explica que o termo foi ganhando força no cenário cultural brasileiro depois da bossa nova e de alguns movimentos, como o tropicalismo, ainda que à contragosto dos próprios músicos.
} 
(antiquários, leilões de raros instrumentos musicais, compra de um pacote anual para concertos e óperas nos teatros municipais etc.) - qual a sua opinião sobre a obra de um Chico Buarque ou Caetano Veloso, sua resposta, ao contrário do que reza o senso comum, será a de se tratar de uma 'monotonia estética', sempre o 'mesmo ritmo', sempre a 'ausência de complexidade' tão 'própria da música clássica' (de concerto). É fato que há grandes músicos populares com uma formação musical erudita, geralmente arranjadores, no entanto, são eles mesmos que fazem questão de demarcar tais distinções: Francis Hime, Júlio Medaglia, respectivamente parceiros de Chico Buarque e Caetano Veloso em importantes obras musicais, são uma prova disso. E podemos mesmo dizer que o papel do arranjador em música é semelhante ao do roteirista no cinema. Pode-se ter uma boa música ou uma boa letra, como se pode ter uma boa história ou um bom argumento, mas se não for feito um bom arranjo, como um roteiro mal-adaptado, toda a qualidade do trabalho pode ficar comprometida. $\mathrm{O}$ arranjador não muda o gênero musical; acrescenta notas, tira palavras, sugere outras etc. Seria de grande relevância saber a formação cultural e origem social dos arranjadores da música popular de vanguarda (jazz, bossa-nova, tropicalismo). Temos a impressão de que os músicos procuraram aproximar-se da música erudita através dos arranjadores com vistas a dar maior legitimidade ao seu trabalho (Os arranjos da música Tropicália de Caetano Veloso, por exemplo, foram feitos por Júlio Medaglia, maestro de formação).

No entanto, historicamente, a relação entre música popular e música erudita foi sempre muito tensa. Nos EUA, Europa e América Latina, a tentativa de aproximação partiu sempre dos músicos populares; eles visavam com isso rentabilizar prestígio para si e para os gêneros musicais de que eram representantes (Hobsbawn, 1990, 1998; Calado, 1990). O músico erudito foi (e continua sendo, em que pese o discurso politicamente correto) sempre muito reticente em se aproximar da música popular e quando o faz trata-se de se referir a ela como algo 'importante a ser estudado', mas sempre como algo externo a ele, uma nova roupagem para o que se chama folclore e exótico ${ }^{3}$. Quando Villa-Lobos refere-se ao seu interesse pela música e instrumentos populares, como o violão, e a proibição de seu pai de que ele se aproximasse do vulgo, tendo que estudar violão escondido, tal argumento não expressa apenas as angústias de um jovem romântico que quer mergulhar de corpo e alma na cultura popular, como objetivava a sua geração; também almeja deixar claro que antes de seu interesse por uma prática cultural extremamente rica, mas desprestigiada, ele é um músico erudito, de um

\footnotetext{
${ }^{3}$ Há inúmeros exemplos em outras áreas culturais; na literatura, Sartre (1961), em sua autobiografia, deixa bem claro a sua posição com relação às leituras de bancas (kiosque à jornaux) em oposição à literatura do cânone.
} 
ambiente erudito, isto é, ele detém os instrumentos necessários para decodificar uma prática cultural legitimada: a música de concerto. As reticências do músico erudito não são outra coisa senão uma maneira de manter o seu prestígio, legitimado pela tradição, como um dos últimos estetas na era da reprodutibilidade técnica. Assim não será exagero tomar a orquestra sinfônica, sem nenhum sentido pejorativo, como uma comunidade de estetas tendo como referências valores qualitativos em oposição à sociedade individualista regida por valores quantitativos.

\section{Ouvir e escutar}

O julgamento estético (de valor) é mais intenso na música, pois essa nos impressiona imediatamente. Paradoxalmente, a arte mais 'subjetiva', de interiorização, universalizante é a que está mais próxima das complicadas equações e sistematizações científicas. Quando criança, quase todos escrevemos poemas, rabiscamos desenhos, representamos. Uma composição musical, todavia, no imaginário ocidental, só um virtuose poderá fazê-lo. Compor uma música (não estamos nos referindo à letra) significa dominar a notação musical, algo característico da música moderna no ocidente: "uma obra de arte musical moderna, por menos complicada que seja, não poderia ser produzida, nem transmitida, nem reproduzida sem os meios de nossa notação: sem ela uma obra musical moderna não pode em geral existir em lugar algum e de nenhuma maneira, nem mesmo como uma propriedade interna de seu criador." (Weber, 1995, p. 119). Não à-toa o "gênio precoce", mito moderno nascido no romantismo nos finais do século XVIII e que tem em Mozart seu tipo-ideal, ser reconhecido principalmente, pelos homens de seu tempo, na arte musical. Em outras artes este reconhecimento pelos contemporâneos é possível? - Dificilmente. Alguns exemplos: na literatura, o nome de Arthur Rimbaud; e, atualmente, muitos poetas e artistas adolescentes da contracultura, mortos por overdose, suicídio e outras mortes românticas, vêm sendo "descobertos" pela crítica estadunidense e européia; nas artes dramáticas os "gênios" costumam desaparecer quando adultos - no cinema, exceto pesquisadores e diletantes, ninguém mais se lembra de Shirley Temple ou de Macaulay Culkin; e também no Brasil temos essa miríade de atores-mirins que nunca mais ouvimos falar quando a telenovela termina. Em suma, mesmo que consideremos a maioria dos artistas consagrados pela genialidade precoce, tal reconhecimento, todavia, dá-se geralmente pelas gerações seguintes. 
O julgamento estético sobre música que encontramos nas análises de vários trabalhos de sociologia, de crítica cultural dos grandes jornais e revistas culturais de prestígio são julgamentos de gosto. Comparar uma letra de rap com uma composição tropicalista ou um samba de Chico Buarque com uma música clássica para 'medir' o seu 'valor' estético é infrutífero se quisermos uma compreensão objetiva das propostas que os diferentes estilos musicais propõem para o enriquecimento da linguagem musical. Essas afirmações ultrapassam o relativismo ingênuo e conservador. O importante a salientar é que antes de fazermos uma comparação, é preciso saber se há a possibilidade objetiva de comparação. (Comparar bananas com laranjas é possível na medida em que estamos interessados em determinadas propriedades comuns a todas as frutas. Já as propriedades das bananas só podem ser obtidas se compararmos elas mesmas.) Que um indivíduo não se identifique ou não consiga fruir esteticamente a obra machadiana ou uma obra surrealista ou naturalista ou qualquer outra, não significa que tais obras não tenham ou possuam um valor estético.

O julgamento de gosto tomado como um julgamento estético advém de uma nítida confusão conceitual entre 1) ouvir e 2) escutar: "o primeiro inclui outros estímulos além da música, e pode ser um acompanhamento para outras atividades. Escutar requer concentração, restringindo-se somente aos estímulos musicais articulares" (Walton, 1972, p. 95-96; apud Callado, 1990, p. 159) ${ }^{4}$. É claro que na realidade essa diferenciação não aparece concretamente àqueles que usufruem esteticamente uma obra musical. Mas, para o crítico que se debruça sobre a música como uma importante prática cultural, no entanto, tal diferença é de grande relevância. Mesmo quando muitos estudiosos afirmam não estarem interessados na questão estética de um determinado fenômeno cultural (já que ultrapassa o seu campo de análise), interessados apenas no significado e importância históricos ou em sua relevância política, é difícil não encontrar em tais trabalhos análise estética que são na verdade julgamentos de valor.

Um crítico literário não se debruça ante uma obra literária do mesmo modo que um leitor interessado vai a uma livraria, adquire-a e a lê. Se assim o fizesse não haveria necessidade de crítica literária (ou quaisquer outras críticas), de revistas de literatura ou cursos universitários. O papel do crítico não se reduz a afirmar que a obra é influenciada pelo seu contexto, etc., isso é óbvio. O que interessa saber é como esse contexto estrutura-se

\footnotetext{
${ }^{4}$ Se na musicologia, como na sociologia, há muitas vezes uma infinidade de conceitos para falar sobre o mesmo fenômeno, tal distinção perpassa a disciplina e é importante para a avaliação estética de gêneros e estilos musicais. Quando um musicólogo (Schafer, 1991) sugere-nos um ouvido pensante, propõe-nos, sobretudo, uma educação musical que ultrapasse o mero ouvir, que escutemos.
} 
internamente no texto, isto é, como os indivíduos que produzem uma obra cultural captaram e lidaram com as contradições de seu tempo. Era isso o que queria dizer Barthes (2002) quando afirmou que o papel do crítico - como o do gourmet - é auxiliar o leitor a ler melhor, ajudar o fruidor a ter mais e melhor prazer estético, e não simplesmente fechar a obra com conceitoschave de uma disciplina acadêmica. Obras, segundo o crítico francês, são como pratos; precisamos aprender a degustá-las. Os julgamentos estéticos na crítica musical contemporânea estão mais para os do leitor interessado do que para os do crítico com embasamento teórico.

A análise de uma obra deve ser feita dentro de sua proposta: qual é a sua recusa estética e até onde ela chegou com vistas àquilo que propunha? Quanto maior o grau de coerência e de aproximação aos objetivos propostos inicialmente, maior será a probabilidade e possibilidade de uma determinada obra ser reconhecida e valorizada em termos estéticos ${ }^{5}$. A sociologia já demonstrou a conexão entre um meio de expressão artístico - como a música ou o teatro, por exemplo - e sua articulação com os grupos sociais que o produzem e o consomem. O valor estético, para ser legítimo, também depende da articulação artista-obrapúblico-instituiçoes-credibilidade. O fato de um artista ser valorizado numa época, esquecido em outra, ou (re)descoberto posteriormente, exemplifica o argumento.

Porém, a crítica cultural, ela própria um produto da cultura, ao enfatizar que a sua esfera, assim como as outras (a política, a economia, o direito) encarna os conflitos, discursos e relações de poder no contexto histórico e social em que se apresentam, corre o risco de se enforcar na corda que teceu para resgatar dos mares esfera cultural os agentes inconscientes subjazidos no julgamento estético. Se ela questiona a (suposta) autonomia da estética, o valor dessa última tende a subsumir seja com o argumento de que o sociólogo 'não está interessado no valor estético' de um fenômeno cultural ou de um determinado meio de expressão artístico, seja com o argumento de que a própria fragilidade da cultura na sociedade capitalista indica a pouca relevância (sociológica) do valor estético intrínseco à obra. Para o sociólogo, o valor estético não deve ser tomado como um campo diverso do seu e nem como tema secundário do ponto de vista da disciplina. A Estética autonomizou-se ${ }^{6}$, tornou-se uma esfera social com suas próprias regras do jogo, e o exemplo de tal emancipação são a enorme

\footnotetext{
${ }^{5}$ A crítica aos músicos e poetas dos CPCs de barateamento da linguagem tem graus de injustiça. É preciso perguntar-se, antes de julgá-los indistintamente, quais deles conseguiram expressar esteticamente aquilo que propunham (a arte como política).

${ }^{6} \mathrm{Na}$ ementa de um curso universitário de Estética, lemos: "O fio condutor do curso será a discussão de questões como as seguintes: o que é o prazer estético, o belo, qual a sua relação, se é que existe, entre sua produção e o meio em que é gerado, qual a relação entre forma e matéria dos objetos estéticos, que é arte, etc”. (Unicamp. Catálogo dos Cursos de Graduação, 2004, p. 564) [Grifo nosso]
} 
quantidade de livros editados anualmente em seu nome, as disciplinas universitárias que levam o seu nome, os cursos de férias oferecidos em instituições com o seu nome, além, naturalmente, dos especialistas chamados a opinar, em seu nome, sobre os "valores estéticos" de uma infinidade de objetos a serem consumidos pela sociedade contemporânea.

Assim, ao desemaranhar-se o que é regido pelo senso comum, é preciso atentar-se para não sermos ludibriados pelo senso comum do seu próprio meio - das categorias de análise das disciplinas - e que pode ser ou mais ou menos sofisticado dependendo da posição dos agentes. Talvez por causa de sua função negativa como "destruidora de mitos" (Elias, 1980) mitos modernos principalmente - a sociologia não tenha a simpatia de muitos, ainda que seja preciso um contínuo exercício de reflexividade para que o destruidor de mitos não se torne um novo mito, cegando-o para o conhecimento da realidade objetiva dos fenômenos analisados.

A dicotomia cultura popular x cultura erudita, intrínseca nos trabalhos acadêmicos sobre a(s) cultura(s), não dá conta da cultura consumida pelas classes sociais. Que há uma polarização entre ambas, devido aos conflitos e tensões intrínsecos à esfera da cultura, é fato. Porém, muitos músicos populares não fazem parte do gosto das classes populares; a música popular de vanguarda poderia ser chamada antes de uma arte média. É um produto cultural produzido por grupos e indivíduos intelectualizados de uma classe específica com um interesse pela cultura popular (O programa TIM Festival de Música veiculado num canal de TV é um dentre inúmeros exemplos; havia duas categorias de premiação: melhor cantor(a) popular e melhor cantor(a) de MPB).

O fato de alguns indivíduos serem originários das classes populares não significa que eles mantenham suas "raízes" populares". Quando jovens de origens modestas chegam a Universidade, socializam-se num novo ambiente cultural e a consomem. São quatro os tipos de cultura discutidos, consumidos, prestigiados nos meios universitários, institucionais e governamentais: 1) a cultura popular tradicional, isto é, de grupos sociais que buscam preservar suas tradições (como as culturas caipira, quilombola e algumas indígenas) e que parece servir de material exótico a estudiosos e diletantes da cultura folk; 2) a cultura das classes populares urbanas, das quais os artistas daí originados (os músicos de estilos como

\footnotetext{
${ }^{7}$ Quando A. Camus, numa polêmica com Sartre, argumentou com ares de ressentimento que ele, ao contrário do seu amigo, tivera uma infância difícil e origem proletária, o filósofo francês arrebatou, não exatamente com tais palavras, que hoje Monsieur A. Camus escreve, publica, vive em Paris; um dia ele foi das classes proletárias, hoje não mais; ontem era oprimido, hoje oprime, como Sartre; hoje, é um autêntico burguês, como Sartre. Essa retórica da lamentação de Camus abre muitas portas atualmente e vem fazendo sucesso na cultura contemporânea, principalmente nas artes audiovisuais (cinema, televisão e documentários).
} 
pagode, funk, sertanejo etc.) são rentabilizados pelos homens de negócios das grandes empresas do entretenimento e da TV; 3 ) a cultura popular de vanguarda (como o tropicalismo, bossa-nova), isto é, as artes das classes médias; 4) a cultura erudita, a cultura canonizada e legitimada pela tradição. É incrível a distância entre as suas referências culturais concretas misto de cultura popular com a cultura de massa produzida pela indústria cultural, desprezadas e mal-vistas nos meios universitários - com as discussões feitas sobre cultura popular (folclore e a arte média) no meio acadêmico.

\section{Técnica e sofisticação}

A crítica do universitário intelectualizado à 'pobreza estética' de um gênero musical como o rap também tem um fundamento sociológico de grande relevância: o predomínio da racionalidade técnica. Sabe-se que uma das características da modernidade é a crescente especialização e autonomização das diferentes esferas da vida social - economia, política, cultura, direito etc. - e das inúmeras técnicas que produzem para adaptarem-se às regras do jogo. Quanto mais um indivíduo tiver o domínio de uma especialização técnica 'necessária ao desenvolvimento social', maior sua inserção e prestígio sociais; basta notar que os acadêmicos e professores de hoje não tem nada em comum com o scholar anglo-americano ou maitrepenseur francês tão comuns até os anos 1960, Se hoje sabe-se cada vez mais de cada vez menos, o scholar era alguém que sabia não só de coisas, mas também das coisas e especializava-se em um tema porque tinha (e era o que lhe permitia) uma formação não só ampla, como sólida.

Essa especialização também ocorre na esfera da cultura com o surgimento, na modernidade, do virtuose, o "artista profissionalmente educado para a execução virtuosa de sua arte", primeira e especialmente no seio musical (Weber, 1995, p.119). É nesse contexto que também surge, por exemplo, os diferentes gêneros literários e artísticos com os seus especialistas. Fala-se então no romance como uma técnica, nas técnicas da pintura, posteriormente na técnica da fotografia e com o cinema as diversas técnicas e etapas na elaboração de um roteiro, como na maioria dos livros especializados sobre roteiro adotada nos cursos universitários de comunicação social e cinema e vídeo (onde encontramos sempre um capítulo intitulado As técnicas do Roteiro; O Roteiro e suas técnicas etc.). Assim é que o crítico de cultura, independentemente de suas referências intelectuais e teóricas, pode falar ou 
escrever com entusiasmo de um artista (músico, escritor, pintor, bailarino) que 'sua genialidade advém dele dominar todas as técnicas de sua arte' - e tal afirmação, aliás, é um chavão tanto da crítica especializada quanto dos críticos-jornalistas (ou jornalistas-críticos) da grande imprensa, chavão que está para a cultura do mesmo modo que os termos democracia e participação estão para os partidos políticos (pois tanto o centro quanto a esquerda, a direita e seus 'extremos' abusam do vocabulário). Se o conceito de progresso está relativamente abalado hoje em dia, a legitimidade da idéia de se dominar uma técnica, salvo engano, jamais foi questionada: o profissional técnico-especialista cada vez mais almejado na esfera do trabalho e da economia, e o virtuose, cada vez mais aplaudido na esfera da cultura, são indivíduos que desempenham o mesmo papel social nestas duas importantes áreas da sociedade contemporânea.

Na produção de um rap não se exige uma sofisticação técnica. Não se exige dos atores que eles dominem determinado tipo de instrumento, em suma que dominem uma técnica instrumental. O único conhecimento técnico importante é a manipulação do aparelho sonoro pelo Disc-Jóquei, o DJ; ele o manipula arranjando as bases rítmicas sobre a qual o compositor de rap encaixa a sua letra. O rapper insere na base sonora das sessões rítmicas de uma música já gravada as suas poesias; mais nada, absolutamente mais nada. Para o rapper, a questão da originalidade (e talvez da autonomia) é secundária. Ele sabe da capacidade da indústria cultural de absorver o novo transformando a (suposta) novidade em "mais do mesmo". Se na indústria cultural o novo vira pastiche, o rapper tenciona apropriar-se desse novo pastichizado, isto é, das bases rítmicas de uma determinada música, com o intuito de ressignificá-la. Ele se opõe ao virtuose, ao menos sob a perspectiva dessa análise. ${ }^{8}$

Tal forma de produção musical conduz a crítica, muitas vezes implicitamente, ao raciocínio de uma simplicidade (ou pobreza) estética. A crítica moderna estabelece uma hierarquia de que quanto mais complexa do ponto de vista da técnica apresentar uma obra, quanto mais se exigir do produtor cultural um pleno domínio técnico na elaboração de seu trabalho, maior o seu valor estético: as noções de Mais e de Menos (em substituição às de melhor, pior, bem feito, mal-feito) são termos quantitativos que imperam na crítica estética contemporânea travestidos de conceitos qualitativos.

Também os jovens artistas que iriam fazer o tropicalismo tinham para si que a técnica local (atrasada) era insuficiente para a realização dos seus trabalhos estéticos. Quando

\footnotetext{
${ }^{8}$ Refiro-me aqui a esse exército anônimo de jovens que fazem o hip-hop no dia-a-dia e não aos grupos lançados pelas gravadoras para aproveitar o sucesso momentâneo de um determinado fenômeno cultural. Vide o trabalho de Silva, 1998.
} 
Caetano Veloso simula sua própria morte em uma de suas apresentações, ele não está apenas frustrando a expectativa de violência das massas como queria Glauber Rocha (Estética da Fome; Estética do Sonho). É a morte do atraso técnico e o louvor da tecnologia enquanto extensão da técnica (como até hoje nos discursos de Tom Zé) para a "maior expressão" de sua arte (a guitarra, os modernos instrumentos de sopro, os amplificadores etc.). Algo similar ocorre na mesma época com o jazz. O jazz fusion (a fusão do jazz com elementos musicais totalmente estranhos a ele) até hoje costuma dividir os seus críticos. Quando Miles Davis (1926-1991), influenciado por Jimmi Hendrix e pela contracultura, talvez pela primeira vez na história do jazz abusou dos amplificadores no trompete e abandonou o "estilo moderninho" do jazzista - terno, gravata e sapato - por roupas 'exóticas' e/ou primitivas provindas dos trópicos, ele causou verdadeiro espanto entre os admiradores do gênero. Winton Marsalis nos anos 1980 chegou a reivindicar uma volta às tradições autênticas (sic!) do jazz, e L.F. Veríssimo, por exemplo, escreveu em algum lugar que parou de ouvir jazz quando Miles Davis começou a usar sandálias. Embora o 'estilo' Miles Davis tenha sido incorporado pela indústria cultural nos anos seguintes, o importante a ser notado é o fato de que a juventude, tanto no primeiro quanto no terceiro mundo, emerge historicamente enquanto um grupo social específico, buscando referências ('exóticas') em outros países com a intenção do choque, e as influências foram de ambos os lados e não via de mão única. $\mathrm{O}$ artista na periferia do capitalismo com todos os seus complexos de inferioridade, mas também de aguça criatividade (Ianni, 1977) ao reelaborar o que é velho, transformando-o em algo novo. É surpreendente como essa influência recíproca é pouco citada pelos estudiosos do assunto (tanto brasileiros quanto brasilianistas); isso talvez se explique pelo fato da noção de imperialismo cultural ser tomada como algo dado a priori pela maioria dos estudiosos da cultura que se debruçam sobre essa época.

A crítica ao "barateamento da linguagem" é, na verdade, a crítica do atraso das técnicas então disponíveis como recursos para uma melhor utilização estética da linguagem. A importância (estética) da forma para os concretistas na elaboração poética é também um avanço na técnica que o poeta precisa dominar para expressar o mais virtuosamente possível os seus desejos (e só se deseja o que não se tem). Lembremos aqui que o poeta é o nãoromancista, como o romancista é o não-poeta. Mesmo os escritores que dominam várias modalidades da escrita costumam ser reconhecidos em apenas uma delas, geralmente naquela em que ele conseguiu a máxima virtuosidade, segundo a crítica; a ideologia da especialização técnica é de uma grandeza tal que a tendência da crítica cultural contemporânea é considerar 
a priori que "o artista" só pode dominar plenamente uma área. Basta notar os ganhadores do Prêmio Nobel de Literatura nos últimos vinte e cinco anos: $\underline{O}$ romancista (Saramago); $\underline{O}$ poeta (Derek Walcott); $\underline{O}$ dramaturgo (Dário Fo); $\underline{O}$ ensaísta (Elias Canetti) ${ }^{9}$.

Se tivermos em mente a noção de técnica tal qual exposto não é difícil compreender porque apenas com o uso de instrumentos musicais mais avançados tecnicamente (guitarras), misturados aos seus instrumentos tecnicamente atrasados (geralmente de percussão), a música de vanguarda - a MPB - procura romper com esse tão propagado e odiado "barateamento da linguagem" por parte dos nacionalistas culturais. A crítica ao barateamento da linguagem feita pelos virtuoses não se deve somente ao fato da 'pobreza' da linguagem, mas também à finalidade prática (política) almejada. Com o processo de autonomização estética, na qual o virtuose domina a técnica de sua arte por ela mesma, em si mesma, a técnica da arte pela arte, a idéia de instrumentalizá-la, angustia-lhe a má consciência do cristão que peca e mesmo muitos artistas politizados de seu tempo têm aversão aos usos práticos de sua arte e suas obras. Assim como a esfera jurídica não aceita ser instrumentalizada para finalidades que ultrapassem o seu domínio; assim como a esfera religiosa não aceita (em teoria) ser instrumentalizada para fins políticos ou mundanos: "Dai, pois, a César o que é de César e a Deus, o que é de Deus", segundo o profeta religioso (Mateus 22:21); assim como as esferas econômica e política não aceitam ser instrumentalizadas para fins religiosos; também o virtuose (o Sol da esfera estética), salvo em regimes ditatoriais quando a própria vida está em jogo, não aceita ser instrumentalizado por nenhuma delas: “A emoção pela emoção é a finalidade da arte; e a emoção pela emoção é a finalidade da vida, assim como daquela organização da vida com fins práticos à qual damos o nome de sociedade'. (Wilde, 1995, p. 39). Esse aforismo sintetiza toda a weltanschauung ("visão-de-mundo") do artista, do esteta, do virtuose em suma.

Isso é ainda mais nítido na arte contemporânea a partir dos anos 1970. Com o esfacelamento dos projetos coletivos das vanguardas ocidentais no pós-guerra e sua canonização através de prestigiados atores e instituições - museus, bancos, colecionadores - e megaretrospectivas dos gênios artistas do modernismo (Picasso, Dali, Duchamp, Chagall, Kandinski, Frida Kahlo, Os Muralistas latino-americanos) rodando as principais metrópoles mundiais, vê-se o discurso reivindicador de plena autonomia: “Achille Bonito Oliva, no libelo

\footnotetext{
${ }^{9}$ No século XX, a exceção talvez seja J-P Sartre que, salvo a poesia por razões intelectuais, dominou todas as modalidades da escrita: o romance, o conto, o teatro, o roteiro, o ensaio, o tratado filosófico. Todavia, ainda assim persiste uma oposição entre aquele que domina a técnica da narrativa e aquele que domina a técnica da poesia.
} 
A Transvanguarda, de 1979, caracterizou a produção artística dos anos 70 (...) pela 'retomada da posse da subjetividade do artista' e pela 'singularidade da obra criada'. O artista, com o fim das poéticas vanguardistas que confinaram a obra à realização de um projeto (teórico e coletivo), voltou-se, segundo Oliva, para seu 'imaginário individual, sem preocupar-se com a unidade e a coerência de seus trabalhos'. 'Signos pessoais' de sua história individual (seus 'pequenos pensamentos e mínimas sensações'), acrescenta, foram associados livremente aos ‘signos públicos da história da arte e da cultura(...)." (Fabbrini, 2002, p. 29). Em suma, não há nenhum programa, nenhum romantismo, nenhuma utopia na arte 'legítima' contemporânea, e não é em vão que a crítica atualmente divida a arte em antes e depois das vanguardas.

\section{A virtuosidade da crítica}

Tornou-se senso comum nas ciências humanas do século XX (sociologia, historiografia, antropologia, crítica literária), em que pese as divergências teóricas e estilos de pensamento, a afirmação de que o produtor cultural (o 'artista') não se faz apenas por si, por seus méritos somente, mas depende de outros agentes e instituições que lhe servirão de alicerce até que ele consiga 'aguentar-se sobre os próprios pés'. No entanto, pouca atenção foi dada ao fato de que não só os agentes - instituições e críticos - são indispensáveis para que se forme e se eduque o virtuose, como também o próprio virtuose forma o crítico especialista de sua área (literatura, música, artes visuais, cinema etc.). O virtuose precisa ser reconhecido por uma crítica, ao menos inicialmente, também virtuosa. Poucos intelectuais compreenderam tão bem essa relação de subjetividade/objetividade quanto Júlio Cortazar; em 'O Perseguidor', a relação do virtuose (um jazzista no auge da maturidade e expressão artísticas) com o seu crítico e biógrafo é de uma intensidade tal que esse último torna-se virtuosamente dependente do ethos do primeiro. O crítico vive dele, nele, para ele. Mas, a idéia de uma crítica virtuosa vinda à luz pelos nexos (históricos, estéticos, afetivos, políticos) de sentido que amarraram um ao outro, ganha importância na medida em que essa relação é socialmente reconhecida pelos diversos sujeitos e grupos tanto pertencentes aos diversos domínios da esfera cultural (música, literatura, cinema, dramaturgia etc.) e 'cientificamente' legitimada pela academia (pelos estudiosos das ciências humanas e das artes). (Atualmente, os agentes e instituições que formam a esfera da cultura são: os próprios artistas que fazem a cultura; as instituições 
culturais privadas e seus intermediários como curadores e/ou marchands que negociam e avaliam a cultura dos artistas; os colecionadores, que especulam e enriquecem com ela (vide os leilões); o Estado que, por intermédio de incentivos fiscais, financia o seu desenvolvimento; as empresas que, além de agregar valor simbólico às suas marcas através dos produtos culturais (filmes, peças, livros, exposições, catálogos etc.), também agregam valor material, pois podem abater o investimento no pagamento de impostos; e por fim os acadêmicos que estudam a cultura enquanto mais uma esfera social relativamente autônoma, ao lado de outras - econômica, política, jurídica etc.)

Assim é que se fala (e falar é instituir aquilo de que se está a falar) de que todo grande pensador tem um artista (virtuose) a quem admira e a quem de certo modo lhe forneceu subsídios tanto para a formação de seu pensamento quanto para o seu prestígio enquanto especialista de determinada área. Fala-se então em Marx e seu Balzac, em Lukács e o 'seu' Thomas Mann, Adorno e o 'seu' Beckett, Bourdieu e o 'seu' Flaubert, Antônio Cândido e o 'seu' Graciliano Ramos, Benjamin e o 'seu’ Baudelaire, Sartre e o 'seu' Genet, Schwarcz e o 'seu' Machado de Assis, Alice Walker e a 'sua' Zora N. Hurston, E.P. Thompson e o 'seu' William Morris, Foucault e o ‘seu’ Borges, e, porque não, Arrigucci e o 'seu' Cortazar; a lista é grande. E tanto o aspecto qualitativo da interpretação, quanto o aspecto quantitativo, isto é, a própria forma material sobre a qual se apresenta a interpretação do crítico em relação ao virtuose pode causar um grande efeito. Em palestras, cursos e artigos são freqüentes entusiastas, mais da crítica que dos autores criticados, falarem nas "monumentais 600 páginas' que Sartre dedicou a Jean Genet, nas “incríveis 900 páginas” da biografia de E.P. Thompson sobre o poeta W. Morris, ou nos 'belos e enxutos' ensaios de Antônio Cândido sobre Graciliano Ramos etc.

A virtuosidade da crítica é histórica, podendo ser superada por outros críticos num determinado período, senão superou os críticos da geração anterior, enquanto outras vencem a "tirania do tempo". Um exemplo de êxito é o livro de Edmund Wilson (2004) sobre o simbolismo, até agora insuperável. Por outro lado, que estudante hoje conhece ou lê, dentre outros, Tristão de Athaíde ou J-P Sartre, grandes críticos de suas épocas? Um problema que carece de análises e estudos é o desnível entre a importância que determinados autores tiveram em sua época e o ostracismo no qual suas obras desvanecem no curso de apenas uma geração (ou menos). Mas essas observações também não significam que determinado crítico tenha se debruçado somente sobre o 'seu' autor, ao contrário a produção e interesse intelectual desses críticos costumam ser amplo como pode ser notado pelas suas bibliografias. A nossa 
leitura - fruição estética - está impregnada da leitura virtuosa de determinados críticos. Quando muitos intelectuais afirmam que Balzac compreendeu como poucos as contradições sociais de seu tempo (Berlinck, 1984, p. 59), tal afirmação está baseada, por exemplo, na leitura (virtuosa) de Marx sobre o escritor; os intelectuais, quando lêem o autor francês, já estão armados dessa premissa, ainda que não se dêem conta. Poucos se debruçaram sobre pelo menos um terço dos quinze volumes da Comédia Humana. Que Marx, aliás, tenha afirmado ou escrito algo sobre ele - algo verdadeiro ou falso, bom ou mau - é secundário para o nosso argumento; o que é relevante é o fato de sua interpretação ser reconhecida enquanto tal, enquanto um autor à altura do escritor, um crítico à altura do virtuose, em suma.

Também poderíamos listar no cinema, nas artes plásticas e no teatro uma infinidade de críticos com os 'seus' artistas: o diretor e o 'seu' dramaturgo, o diretor e o 'seu' ator etc. Ou o regente de uma orquestra com o 'seu' compositor e até mesmo o crítico musical com o 'seu' regente e a 'sua' cantora lírica. Também na música popular isso é visível. ${ }^{10}$ Os exemplos são inúmeros e podem ser buscados ao longo de todo o século XX. Um exemplo de crítica virtuosa que superou até mesmo a obra em análise é o ensaio Dialética da Malandragem, de Antônio Cândido (1970) sobre o romance de João Manuel de Macedo, Memórias de um Sargento de Milícias. Sobre a crítica que chegou a ser equivalente à própria obra do autor, podemos citar Mikhail Bakhtin (1895-1970) e sua análise da obra de Dostoievski; o crítico precisou romper com toda uma tradição de abordagem da crítica literária ocidental, e criar novos conceitos, como o de romance polifônico, por exemplo, para dar conta da grandiosidade de um virtuose. Que fique claro que as afirmações aqui de superação e equivalência não são mera opinião nossa, e sim como essa crítica é reconhecida pelos seus pares no universo cultural em que esses autores estão inseridos.

Isso não significa que tais críticos foram os únicos a interpretar a obra de determinado autor, ou que só tenham se debruçado sobre ela, e a revelar aspectos antes ignorados; mas antes que a virtuosidade de sua crítica (ou originalidade ou qualquer outro nome que se queira dar) atingiu (ou assim foi reconhecida) um grau equivalente e muitas vezes até superior à expressão virtuosa alcançada pelo virtuose em sua arte.

\section{Músicos e músicas: questão de método}

\footnotetext{
${ }^{10}$ Um exemplo de crítica que se pretende virtuosa (mas mais emotiva do que analítica em nossa opinião) é o livro de Zuza H. de Mello (2004) sobre João Gilberto.
} 
A opinião de um jovem da Geração MTV sobre música de concerto será provavelmente sobre a sua 'lentidão', a sua 'velhice' e mesmo muitos, senão a maioria, dos indivíduos intelectualizados das classes médias não habituados à música de concerto, por não fazer parte do seu gosto, também concordariam, mas dificilmente o diriam explicitamente numa pesquisa, por causa da perda de prestígio e do 'vexame da ignorância'. O músico erudito, por exemplo, nem se posiciona sobre um gênero como o rap, como anteriormente não se posicionava sobre o jazz, por exemplo, segundo o historiador Eric Hobsbawn (1998, p. 355) quando afirmou, por exemplo, que nenhum outro autor escreveu tantas idiotices sobre o jazz quanto Adorno (músico erudito). O historiador tem razão quando aponta muitas idiotices escritas sobre o jazz pelo sociólogo alemão, mas suas ressalvas quanto a abordagem sociológica da cultura advém antes de tudo das diferenças de abordagem de um mesmo fenômeno - a cultura - pelo sociólogo e pelo historiador. O interesse do historiador é reconstituir, num determinado período histórico, as práticas culturais de um determinado agente e/ou o significado histórico de um determinado fenômeno cultural. O sociólogo da cultura tende a ir diretamente para a análise de uma determinada prática ou fenômeno cultural, buscando compreender através delas as 'matizes universais' que regem a sociedade que permite com que esses fenômenos/práticas aconteçam. Quando o historiador Eric Hobsbawn debruça-se sobre o jazz, o seu interesse é saber como esse fenômeno cultural originário de um grupo subalterno conseguiu inserir-se e ganhar espaço na corrente principal (mainstream) da 'boa música' no Ocidente. Uma das razões históricas é a própria posição hegemônica dos EUA, que contribuiu para o desenvolvimento e expansão do jazz, além desse gênero ter sido, segundo o autor, a grande contribuição americana para a música popular de vanguarda. Os escritos de Adorno sobre o jazz não refletem apenas a mera "recusa estética" desse gênero, para o qual nunca teve simpatias; visa apenas, tomando-o como ponto de partida, demonstrar um fenômeno novo no mundo moderno: a indústria cultural. Ele não se debruça sobre o jazz enquanto uma prática cultural específica de um grupo social específico porque não é esse o seu foco. Quem quer que tenha lido os seus textos sobre o tema notará que não há referência alguma sobre as personalidades jazzísticas, os estilos ou composições. Muitas das polêmicas que se alastram entre historiadores e sociólogos advêm, talvez, do fato de lermos os trabalhos uns dos outros, escritos de uma perspectiva diversa da nossa, a partir da nossa própria perspectiva - historiográfica ou sociológica.

\section{Referências}


ADORNO, Theodor. "Moda Intemporal - sobre o jazz"; "Réplica a uma crítica a Moda Intemporal”. In Prismas - crítica cultural e sociedade. São Paulo: Ática, 1998.

BARTHES, Roland. O prazer do texto. São Paulo: Perspectiva, 2002

BERLINCK, Manoel T. CPC da UNE. Campinas: Papirus, 1984.

CALLADO, Carlos. O Jazz como espetáculo. São Paulo: Perspectiva, 1990.

CÂNDIDO, Antonio. Dialética da Malandragem. Revista do Instituto de Estudos Brasileiros, n. 8, IEB/USP, 1970, p. 67-89. (In O Discurso e a Cidade. São Paulo: Duas Cidades, 1993.)

CORTÁZAR, Julio. Eı Perseguidor. Buenos Aires.

ELIAS, Norbert. Introdução à sociologia. Lisboa: Edições 70, 1980.

ELIAS, Norbert. Mozart: Sociologia de um Gênio. Rio de Janeiro: Jorge Zahar, 1995.

FABBRINI, Ricardo N. A Arte depois das vanguardas. Campinas, SP: Editora Unicamp, 2002.

GUIMARÃES, Maria E. A. Do Samba ao Rap: a música negra no Brasil. Campinas, SP: IFCH/Unicamp, 1998. (Tese de Doutorado.)

HOBSBAWN, Eric. Historia social do Jazz. São Paulo: Paz e Terra, 1990.

HOBSBAWN, Eric. Pessoas Extraordinárias: resistência, rebelião e jazz. Rio de Janeiro: Paz e Terra, 1998.

HOLLANDA, Heloisa B. Impressões de viagem - CPC, vanguarda e desbunde: 1960/70. 2. ed. São Paulo: Brasiliense, 1981.

IANNI, Octávio. Imperialismo e Cultura. Rio de Janeiro: Civilização Brasileira, 1977.

LÖWY, Michael; SAYRE, R. Revolta e Melancolia - o romantismo na contramão da modernidade. Petrópolis, RJ: Vozes, 1995.

MELLO, Zuza H. João Gilberto. São Paulo: Publifolha, 2004.

ROCHA, Glauber. "Estética da fome"; "Estética do sonho". In Pierre, S. (Org.) Glauber Rocha. Campinas, SP: Papirus, 1996.

RUBIM, A. A.C. Marxismo, cultura e intelectuais no Brasil. In Moraes, J.Q. (Org.). História do marxismo no Brasil, III. Teorias. Interpretações. Campinas: Editora Unicamp, 1998, p. 305-376.

SARTRE, Jean-Paul. As Palavras. São Paulo: Difel, 1961.

SCHAFER, Adam. O Ouvido Pensante. São Paulo: Editora Unesp, 1991. 
SHUSTERMAN, Richard. Vivendo a Arte: o pensamento pragmatista e a estética popular. São Paulo: Editora 34, 1998.

SILVA, José C. G. Rap na cidade de São Paulo: Música, Etnicidade e Experiência Urbana. Campinas, SP: IFCH/Unicamp, 1998. (Tese de Doutorado)

THOMPSON, Edward P. Os Românticos. Rio de Janeiro: Civilização Brasileira, 2002.

VELOSO, Caetano. Verdade Tropical. São Paulo: Cia das Letras, 1997.

WEBER, Max. Fundamentos Racionais e Sociológicos da Música. São Paulo: Edusp, 1995.

WILDE, Oscar. Aforismos. Rio de Janeiro: Newton, 1995.

WILSON, Edmund. O Castelo de Axel - estudo sobre a literatura imaginativa de 1870 a 1930. São Paulo: Cia das Letras, 2004. 